\title{
AN APPRPORIATE SUGAR-BEET HARVESTING MECHANIZATION FOR BIG-SCALE PROJECT
}

\author{
H. A. Abdel Mawla ${ }^{(1)}$, I. Yehia ${ }^{(2)}$ A. M. El Lithy ${ }^{(3)}$ and, A. Faisal
}

\section{ABSTRACT}

The aim of this research is to choose and evaluate the performance rate of three harvesting machines of sugar beet (lifting machine + topping machine, combined and self-propelled machines) appropriate with big scale projects with three different irrigation-systems (pivot, sprinkler and flood). The summarized results are:

By using pivot irrigation-system, the maximum machine-performance rate of $3 \mathrm{fed} / \mathrm{h}$ ( $81 \mathrm{ton} / \mathrm{h}$ ) was obtained with forward speed of $6.5 \mathrm{~km} / \mathrm{h}$ and 6 rows separated machines for topping and lifting of sugar beet. Meanwhile, the minimum machine-performance rate of $0.91 \mathrm{fed} / \mathrm{h}$ $(24.30 \mathrm{ton} / \mathrm{h})$ was obtained with forward speed of $3.5 \mathrm{~km} / \mathrm{h}$ and 4 -rows combined harvester of sugar beet.

The maximum sugar-beet loss of $8 \%$ was obtained with forward speed of $6.5 \mathrm{~km} / \mathrm{h}$, flood irrigation-system and combined harvesting-machine. Meanwhile, the minimum sugar-beet loss of $3.3 \%$ was obtained with forward speed of $3.5 \mathrm{~km} / \mathrm{h}$, pivot system by using two machines for topping and lifting.

The maximum lifting, loading and harvesting efficiencies of sugar-beet of 99.84, 97 and $96.7 \%$ were obtained with forward speed of $3.5 \mathrm{~km} / \mathrm{h}$, pivot system by using two separated machines for topping and lifting. Meanwhile, the minimum sugar-beet lifting, loading and harvesting efficiencies of 99.6, 92.8 and $92 \%$ was obtained with forward speed of $6.5 \mathrm{~km} / \mathrm{h}$, flood irrigation-system and combined harvesting-machine.

The maximum sugar-beet yield of 27.2 ton/fed was obtained with forward speed of $3.5 \mathrm{~km} / \mathrm{h}$, pivot irrigation-system by using two machines for topping and lifting. Meanwhile, the minimum sugar-beet yield of 16

(1) Prof. and head of Ag. Eng. Dept., Col. of Ag. Al -Azhar U., Assiut.

(2) Prof. and Head Res., Ag. Eng. Res. Inst.

(3) Assoc. Prof., Ag. Eng. Dept., Col. of Ag., Al -Azhar U., Assiut.

(4) Post Graduate Student, Ag. Eng. Dept., Col. of Ag. Al Azhar U., Assiut. 
ton/fed was obtained with forward speed of $6.5 \mathrm{~km} / \mathrm{h}$, flood irrigationsystem by using combined harvesting-machine.

The minimum operation-costs were 17.75 L.E./ton (445.5 L.E./fed) by using 6-rows topping and lifting machines at forward speed of $3.5 \mathrm{~km} / \mathrm{h}$ and pivot irrigation-system. Meanwhile, the maximum operation-costs and were 31.6 L.E./ton (780.9 L.E./fed) by using 4-rows combined harvester at forward speed of $3.5 \mathrm{~km} / \mathrm{h}$ and flood irrigation-system.

\section{INTRODUCTION}

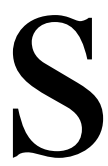

ugar beet is one of the industrial and strategic products of the country. Considering the increase of population and need of sugar, this product has an extraordinary importance 709 thousand tons (about $25.9 \%$ of total production of Egypt) increase in the import of this product emphasizes the special considerations of planners in regard to the increase of sugar beet productions to reduce the imports. The increase in the production of agricultural products usually achieves through development of production factors, fundamental changes of technology or the improvement of technical efficiency.

It is evident that improving agricultural production depends mainly on using improved methods and up-to-date technology through all different agricultural operations. Selection of the appropriate qualitative and quantitative needs concerning agricultural operations of any crop is of great importance to minimize production costs.

Sugar beet is considered one of the most important crops, not only for sugar production but also for fodder and organic matter for the soil. It is also considered as a double benefit crop to the farmers, where the roots are processed for sugar production and the green leaves and tops are used for animal feeding.

Moreover, beet consumes less water than cane by about two-thirds and it may also grow under a wide variety of soil and climatic conditions. The cultivated area of sugar beet in Egypt was about 362 thousand feddens yearly producing about 4.7 million $\mathrm{Mg}$ (ton) with an average yield of 44.2 $\mathrm{Mg} / \mathrm{fed}$ (ton/fed) according to Agric. Statistics Economic Affair Sector, 2011. 
Sugar beet crop is an expensive labor consuming under traditional method. The two main labor-intensive operations of sugar beet production are planting and harvesting. Harvesting of sugar beet is one of the most critical operations. There are many types of sugar beet harvesters which were tested in large-scale Egyptian farms. Some of them were multi rows combined, two machines for topping and lifting. The selection of the appropriate machine for harvesting sugar beet is a vital problem to be considered to minimize both crop losses and operational costs.

Raininko (1990) mentioned that losses during topping operation could be summarized as follows:

1. If the cut of topping is lower than zero levels (the critical section of cutting), the loss is $1.8 \mathrm{ton} / \mathrm{ha}$, and the percentage of sugar in this part is $10.5 \%$;

2. If the cut of topping is lower than zero by $1 \mathrm{~cm}$, loss is 3.3 ton/hectare, and the percentage of sugar is $16.4 \%$ and

3. If the cut of topping is lower than zero level by $2 \mathrm{~cm}$ loss is 3.5 ton/hectare, and percentage of sugar is $17.2 \%$.

Hopkinson (1991) assessed the harvesting losses for 6 row self propelled sugar beet harvesters working in silt clay loam soil under ideal harvesting conditions. One was fitted with "Oppel" wheels, the second with skid and disc lifters and the third with walking shares. Sample areas were dug and cleaned to calculate root losses. Results indicated that harvesting losses under these conditions averaged $2.8 \mathrm{t} / \mathrm{ha}$. Most of this loss was small pieces of beet from root breakage. He also, added that there was a minimal beet left on the surface. All 3 lifting mechanisms achieved an acceptable standard of harvesting loss on this site. No significant yield losses were observed between the three tested mechanism.

Toth (1991) tested the Matrot-M-31 self-propelled harvester which can perform topping, root lifting, cleaning and loading of sugar beet from 6 rows. Test results showed that the harvesting losses remained under $3 \%$ and root damage under $15 \%$ at $3.5-6.4 \mathrm{~km} / \mathrm{h}$ operating speed.

Zaalouk et al. (1996) said that the manual harvesting of sugar beet from one feddan needs about $66,62.04$ and $59.12 \mathrm{man} / \mathrm{h}$ by using hands, hand- 
hoe and hand-shovel, respectively. Meanwhile, the mechanical harvesting theoretically needs only about $1.30 \mathrm{man} / \mathrm{h}$.

Taieb (1990) found that the yield of the sugar beet roots in the manual and mechanical planting was 35.95 and 42.34 ton/fed., respectively. The total demands of energy in the manual and mechanical planting were 0.737 and $50.470 \mathrm{~kW} . \mathrm{h} / \mathrm{fed}$. The cost per one unit of the consumed energy in the manual and mechanical planting was 10.43 and 0.37 L.E/kW.h.

The objectives of the present investigation are:

1. To choose and evaluate the performance rate of three harvesting machines of sugar beet (lifting machine + topping machine, combined and self-propelled machines) appropriate with big scale projects with three different irrigation-systems (pivot, sprinkler and flood).

2. To optimize the forward speed for sugar beet harvesting machines.

3. To evaluate the sugar beet harvesting machines from the economic point of view.

\section{MATERIALS AND METHODS}

The main experiments were carried out through successive agricultural seasons of 2010/2011 at Alexandria Sugar Company farm, Nobaria, El Behira Governorate to evaluate some different harvesting methods of sugar beet crop.

The mechanical analysis of the experimental soil was classified as a sandy soil (table 1). The soil mechanical and chemical analyses (table 2) were conducted in the Soil Testing Laboratory, Desert Development Center, and Research Station in Sadat City.

Table 1: Mechanical analysis of the experimental soil.

\begin{tabular}{|l|l|l|l|l|}
\hline \multirow{2}{*}{$\begin{array}{l}\text { Gravels, } \\
\%\end{array}$} & \multicolumn{3}{|l|}{ Particle size distribution, \% } & Soil \\
\cline { 2 - 5 } & Sand & Silt & Clay & texture \\
\hline 23 & 95.00 & 3.00 & 2.00 & Sandy \\
\hline
\end{tabular}


Table 2: Chemical analysis of the experimental soil.

\begin{tabular}{|l|l|l|l|l|}
\hline \multicolumn{5}{|l|}{ Available level of nutrients, ppm. } \\
\hline $\mathrm{P}$ & $\mathrm{K}$ & $\mathrm{Fe}$ & $\mathrm{Zn}$ & $\mathrm{Mn}$ \\
\hline 12.15 & 141.20 & 3.88 & 1.12 & 1.82 \\
\hline $\mathrm{Cu}$ & $\mathrm{Om}, \%$ & $\mathrm{CaCo} 3, \%$ & $\mathrm{pH}$ & $\mathrm{EC}, \mathrm{dS} / \mathrm{m}$ \\
\hline 0.97 & 0.22 & 3.59 & 8.48 & 3.72 \\
\hline \multicolumn{5}{|l|}{} \\
\hline $\mathrm{Ca}$ & $\mathrm{Ca}$ & $\mathrm{Na}$ & $\mathrm{K}$ & $\mathrm{CO} 3$ \\
\hline 15.29 & 5.71 & 24.56 & 1.84 & 0.00 \\
\hline $\mathrm{HCO} 3$ & $\mathrm{Cl}$ & $\mathrm{SO} 4$ & $\mathrm{SAR}$ & $\mathrm{N}$, \\
\hline 9.29 & 23.49 & 11.69 & 8.91 & 714.00 \\
\hline
\end{tabular}

\section{Materials:}

Sugar beet crop: Sugar beet crop (Beta vulgaris L.) variety was used in this investigation.

\section{Harvesting machine:}

(1) Combined harvester.

(2) Topping machine + lifting machine.

(3) Self-propelled harvester.

The harvesting operation was carried out through four different forward speeds of an average $3.5,4.5,5.5$ and $6.5 \mathrm{~km} / \mathrm{h}$.

(1) Combined 4-rows sugar beet harvester (fig.1):

The combined harvester model EDENHALL 624 consists of two parts:

(a) Front-mounted topping machine and (b) Trailed lifting machine operated in the same time and tractor.

The front mounted topping-machine removes leaves and cuts the beet heads from the sugar beet. And the trailed lifting machine lifts, cleans and unloads into a trailer.

(a) Front-mounted topping machine.

The specifications of trailed 4-rows sugar beet machine are:

Make

Model

Row spacing

No. of rows

Row width

Flail shaft

$1 \mathrm{st}+2 \mathrm{nd}$ cleaner shaft

Depth adjustment
Sweden

EDENHALL 624

45 to $50 \mathrm{~cm}$ mechanically adjustable 4

Adjustable from $45-50 \mathrm{~cm}$

Bolted, spiral arranged steel flails

Rubber flails with sluts in sections over the sugar beet rows manual adjustment to the row width

Lifting cylinder with manual adjustable spindle at the front spindle adjustable rear 
Drive

guide wheels

Required tractor power

1000 rpm PTO shaft

Drive line

From $60 \mathrm{~kW} / 82 \mathrm{hp}$

Wide angle PTO shaft

Scalper unit

Hydraulic driven disc scalpers

(b) Trailed 4-rows sugar beet machine.

The specifications of trailed 4-rows sugar beet machine are:

Make

Sweden

Model

Row spacing

EDENHALL 624

Depth adjustment

Row guiding

45 to $50 \mathrm{~cm}$ mechanically adjustable

Oppel wheels

1 st cleaning unit

2ndt cleaning unit

Lifting cylinder with manual adjustable spindle

Hydraulically drawbar steering

Ground driven, fix mounted with rubber paddles

1 plain roller, 4 spiral rollers and 1 roller pair to centralize the crop flow

Main web followed by axial roller table ( 8 steel rollers) with separately activatable two extracting unit

Bunker filling

Bunker

Ring elevator with bunker filling auger

Unloading elevator $6 \mathrm{~m} 3 / 4$ ton

$1 \mathrm{~m}$ wide, hydraulic swiveling, maximum unloading height 4 meter

Types Pair of 600/55-26.5

Operation

Electro-hydraulic remote control from tractor cab

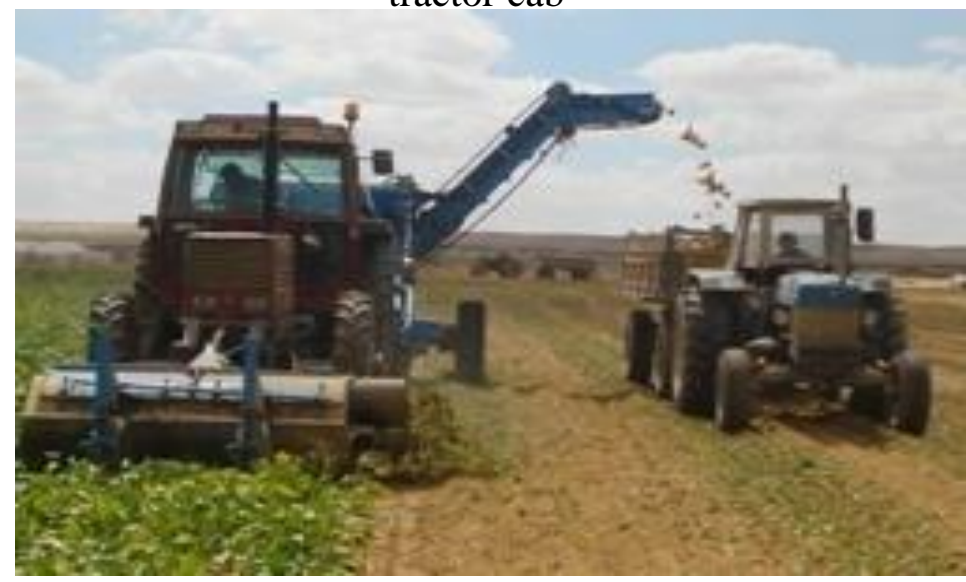

Fig. 1: Combined 4-rows sugar beet harvester. 
Drive

Required tractor-power

Required hydraulics

Drawbar

Length / Width / Height

Mass

Lifting unit

2nd cleaning section

Row guiding

Drive line
1000 PTO shaft

From 99 - $115 \mathrm{~kW}$

Recommended: 110 - $135 \mathrm{~kW}$

1SCV pressure side + pressure less return line

Hitch coupling

$8.1 \mathrm{~m} / 3.5 \mathrm{~m} / 4 \mathrm{~m}$ $7100 \mathrm{~kg}$

Hydraulic driven Oppel wheels with on broad hydraulic

3 turbines in lieu of main web and axial roller table

Automatic drawbar steering with two row sensors

Wide angle PTO shaft

\section{(2) Topping machine + Lifting machine 6 rows.}

The trailed sugar beet topping machine followed with the trailed lifting machine after one day. The powerful topping machine (defoliator) BM 300 is designed to remove leaves from the sugar beet before lifting (lifting). A rotating scalper unit is available as option to perform a clean cutting of the beet heads. The next steps as lifting, cleaning and unloading into a trailer will be done with the 6-row trailed sugar beet harvester Rootster 604. This combination makes the system very efficient as existing tractors can be used.

\section{- Topping machine GRIMME BM-300.}

The 6-row trailed topping-machine (fig. 2) consists of the steel flails of the first row remove the leaves first, behind these; two cleaning shafts rotate in opposite direction and perform the fine cut. This suction effect even captures and chops the weed leaves between the rows. 


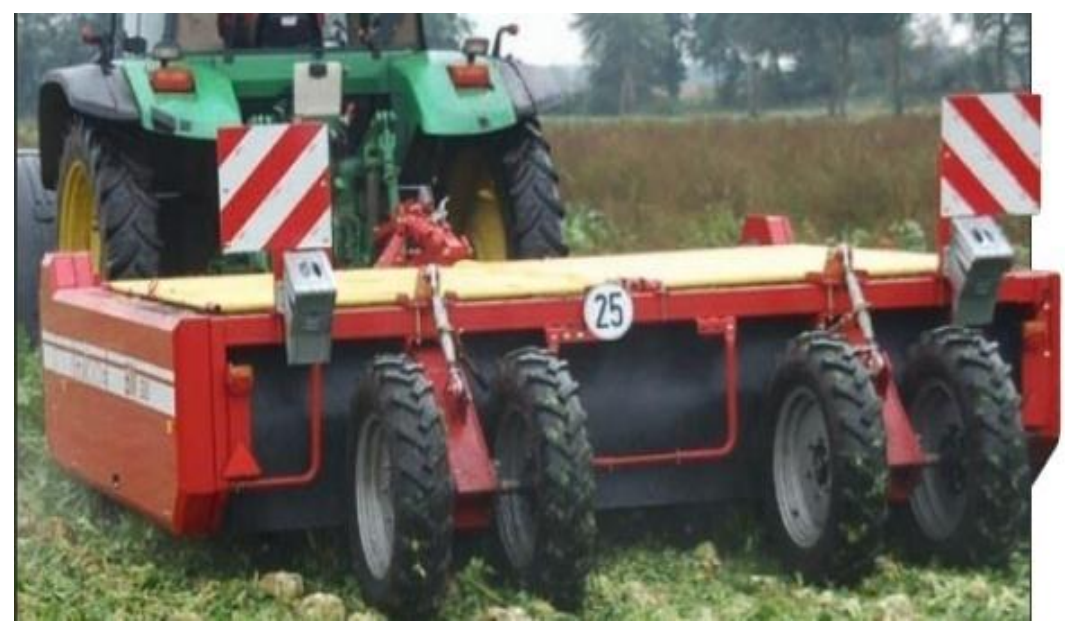

Fig. 2: Topping machine GRIMME BM-300.

The specifications of topping machine are:

Made

Model

No. of rows

Row width

Length/Width/Height

Mass

Flail shaft

$1 \mathrm{st}+2$ nd cleaner shaft

Depth adjustment

Types

Operation

Drive

Required tractor power

Drawbar

Drive line

Scalper unit
Germany

GRIMME BM 300

6

Adjustable from $45-50 \mathrm{~cm}$

$5.6 \mathrm{~m} / 3.3 \mathrm{~m} / 1.65 \mathrm{~m}$

$1950 \mathrm{~kg}$

Bolted, spiral arranged steel flails

Rubber flails with sluts in sections over the sugar beet rows manual adjustment to the row width

Lifting cylinder with manual adjustable spindle at the front spindle adjustable rear guide wheels 4 x $7.5-20$ TR 15 AS

1 single acting independent SCW (raise \& lower the machine) +1 single acting SCW with pressure less return line

1000 rpm PTO shaft

From $60 \mathrm{~kW} / 82 \mathrm{hp}$

Hitch coupling

Wide angle PTO shaft

Hydraulic driven disc scalpers 
- Lifting machine GRIMME Rootster 604 .

The specifications of 6-rows trailed sugar-beet lifting (lifting) machine are:

Made

Model

Row distance

Bunker filling

Bunker

Unloading elevator

Types

Operation

Drive

Required tractor-power

Required hydraulics

Drawbar

Length / Width / Height

Mass

Lifting unit

2nd cleaning section

Row guiding

Drive line
Germany

GRIMME Rootster 604.

45 to $50 \mathrm{~cm}$ mechanically adjustable

Ring elevator with bunker filling auger

$6 \mathrm{~m} 3 / 4$ ton

$1 \mathrm{~m}$ wide, hydraulic swiveling, maximum unloading height 4 meter

Pair of 600/55-26.5

Electro-hydraulic remote control from tractor cab

1000 PTO shaft

From $99-115 \mathrm{~kW}$

Recommended: 110 - $135 \mathrm{~kW}$

$1 \mathrm{SCV}$ pressure side + pressure less return line

Hitch coupling

$8.1 \mathrm{~m} / 3.5 \mathrm{~m} / 4 \mathrm{~m}$

$7100 \mathrm{~kg}$

Hydraulic driven Oppel wheels with on broad hydraulic

3 turbines in lieu of main web and axial roller table

Automatic drawbar steering with two row sensors

Wide angle PTO shaft

(3) Self-propelled sugar beet harvester (fig. 3).

The specifications of 6-rows self propelled sugar beet harvester are: 
Made: France, Company: MOREAU, Model: LECTRA V2, Length, Width and height: 12, $3.3 \mathrm{~mm}$ and $4 \mathrm{~m}$, Row width: Adjustable from 45 $50 \mathrm{~cm}$, Optionally, hydraulically moveable: $45-50 \mathrm{~cm}$, Flail topper series: inline system. Options: high-performance rate defoliator FM 270/300, Depth guidance EHR electro-hydraulic linkage control by means of 7 feeler wheels, depth adjustment can be carried out from inside the cabin, Scalper unit series: Parallelogram guided scalper unit with cutting height automatic,

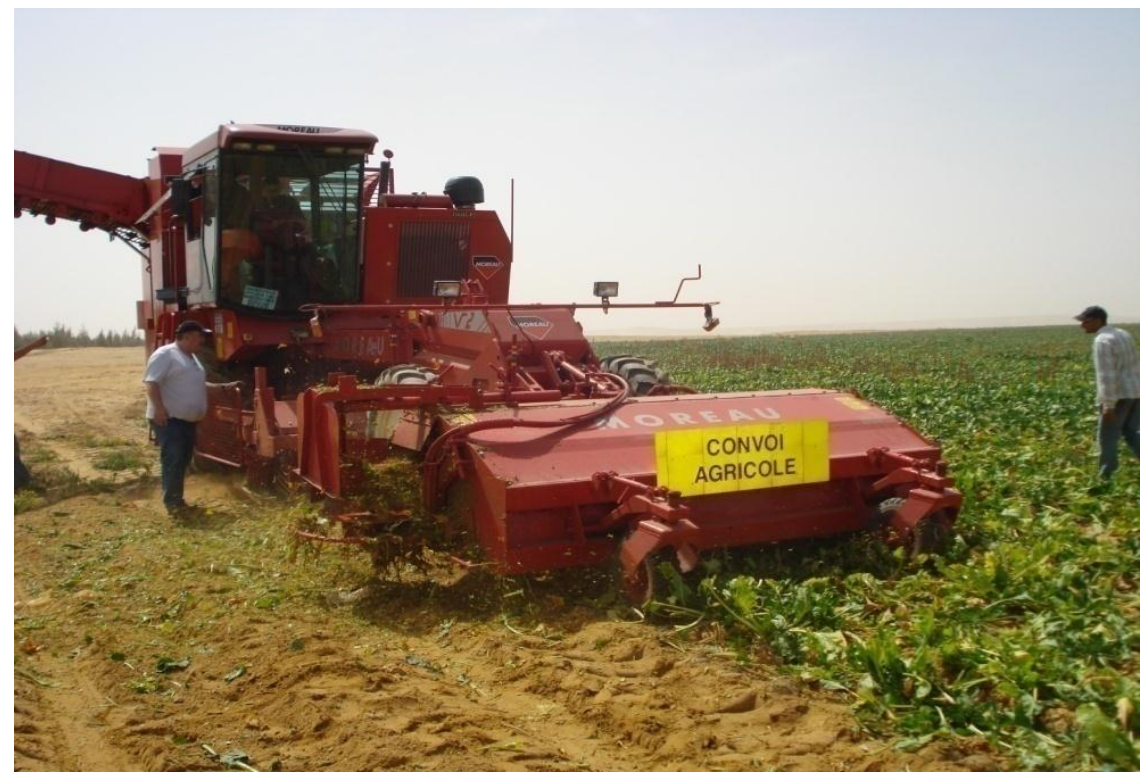

Fig. 3: The self-propelled sugar beet harvester ( LECTRA V2).

\section{Irrigation systems:}

- Flood irrigation: using the conventional method.

- Sprinkler irrigation system.

- Center pivot irrigation system.

Fertilizing and weed control were the same in all treatments.

\section{Measurements:}

- Root yield: The yield (RY) of the harvested roots was determined by massing the roots lifted by harvester, in the mechanical harvesting by using the following equation (Taieb, 1997) was used: 


$$
R_{\mathrm{Y}}(\text { ton } / f e d)=\frac{\mathrm{M} \times 4200}{\mathrm{~A} \times 1000}
$$

Where: $\mathrm{M}=$ Mass of lifted root, $\mathrm{kg}$ and $\mathrm{A}=$ Harvested area, $\mathrm{m}^{2}$.

- Broken beet percentage: The broken beet percentage can be calculated using the following equation:

Broken beet, $\%=$ (broken-beet mass / total-beet mass) $\times 100$

- Bruised beet percentage: The bruised beet percentage can be calculated using the following equation:

Bruised beet, $\%=$ (bruised-beet mass / total-beet mass) $\mathrm{x} 100$

- Beet left on the soil percentage: The beet left on the soil percentage can be calculated using the following equation:

Left beet on the soil, $\%=$ (left beet mass / total-beet mass) $\times 100$

- Un-lifted beet percentage: The un-lifted beet percentage can be calculated using the following equation:

Un-lifted beet, $\%=$ (un-lifted beet mass / total-beet mass) x 100

- Total losses: Total sugar beet losses can be calculated using the following equation:

Total losses $=$ un-lifted mass + damaged-beets mass

Where: damaged beets $=$ broken beets + bruised beets

- Lifting efficiency: The lifting efficiency was calculated according to the following equation:

Lifting efficiency, $\%=100$ - un-lifted beet percentage

- Loading efficiency: The loading-beet efficiency can be calculated using the following equation:

Loading efficiency, $\%=100$ - left beet on the soil percentage

- Harvesting efficiency: The harvesting efficiency of sugar beet can be calculated using the following equation:

Harvesting efficiency, $\%=100-$ total losses percentage

- Fuel consumption: Fuel consumption was recorded by accurately measuring the decrease in fuel level in the fuel tank immediately after executing each operation of 15 minutes.

- Required power: Required fuel-power was calculated by using the following formula (Hunt, 1983): 
FARM MACHINERY AND POWER

$$
\begin{aligned}
P & =F_{c} \times F_{d} \times\left(\frac{1}{3600}\right) \times C . V . \times 4270 \times \eta_{t h} \times \eta_{m} \\
\mathrm{P} & =3.23 \mathrm{~F}_{\mathrm{c}}
\end{aligned}
$$

Where:

$\mathrm{P}=$ Required power $(\mathrm{kW}), \mathrm{F}_{\mathrm{c}}=$ The fuel consumption $(\mathrm{L} / \mathrm{h}$.$) ,$

$F_{d}=$ Density of fuel $(\mathrm{kg} / \mathrm{L})(=0.85$ for diesel fuel $)$,

C.V. = Calorific value of fuel $(\mathrm{kcal} / \mathrm{kg})=104$ for diesel fuel,

$\eta_{\text {th }}=$ Thermal efficiency of fuel, it is assumed about $35 \%$ for diesel engine and

$\eta_{\mathrm{m}}=$ Mechanical efficiency of fuel, it is assumed about $80 \%$ for diesel engine.

- Specific energy: Specific energy can be calculated by using the

$$
\text { Specific energy }(k W . h / \text { fed } .)=\frac{\text { Re quired power }(k W)}{\text { Actual field capacity }(\text { fed } . / h)}
$$

following equation:

Cost analysis: The hourly cost was calculated according to equation of (Awady, 1978) in the following form:

$$
C=\frac{P}{h}\left(\frac{1}{a}+\frac{i}{2}+t+r\right)+(1.2 \text { w.s.f })+\frac{m}{144}, \text { L.E } / h
$$

Where:

$\mathrm{C}=$ Hourly cost, $\mathrm{L} . \mathrm{E} / \mathrm{h} . \quad \mathrm{P}=$ Price of machine, L.E.

$\mathrm{h}=$ Yearly working hours, $\mathrm{h} /$ year. $\quad \mathrm{a}=$ Life expectancy of the machine,

$\mathrm{i}=$ Interest rate/year. year.

$\mathrm{t}=$ Taxes, overheads ratio. $\quad \mathrm{r}=$ Repairs and maintenance ratio.

$\mathrm{m}=$ Monthly average wage, L.E $1.2=$ Factor accounting for lubrications.

$\mathrm{W}=$ Engine power, hp. $\quad \mathrm{S}=$ Specific fuel consumption, $1 / \mathrm{hp} . \mathrm{h}$.

$144=$ Reasonable estimation of monthly working hours.

Operational $\cos t($ L.E./ fed. $)=\frac{\text { Hourly } \cos t(\text { L.E. } / h)}{\text { Effective field capacity }(\text { fed } . / h)}$ 
Operational cost can be determined using the following equation: Cost per unit of production can be determined using the following equation:

Cost per unit of production

$$
(\text { L.E. } / M g)=\frac{\text { Operational } \cos t(\text { L.E. } / \text { fed } .)}{\text { Crop yield }(M g / \text { fed })}
$$

\section{RESULTS AND DISCUSSION}

\section{Effect of forward speed, irrigation system and harvesting machines on machine performance rate.}

Fig. 4 shows the effect of forward speed, irrigation system and harvesting machines on machine performance rate. The machine performance rate increased by increasing forward speed from 3.5 to $6.5 \mathrm{~km} / \mathrm{h}$ for all tested harvesting-machines and irrigation-systems.

By using pivot irrigation-system, the maximum machine-performance rate rate of $3 \mathrm{fed} / \mathrm{h}$ and $81 \mathrm{ton} / \mathrm{h}$ was obtained with forward speed of 6.5 $\mathrm{km} / \mathrm{h}$ and 6-rows separated machines for topping and lifting of sugar beet. Meanwhile, the minimum machine-performance rate rate of $0.91 \mathrm{fed} / \mathrm{h}$ $24.30 \mathrm{ton} / \mathrm{h}$ was obtained with forward speed of $3.5 \mathrm{~km} / \mathrm{h}$ and 4-rows combined harvester of sugar beet.

Increasing the machine performance rate rate by using two separated machines for topping and lifting is due to increasing the width of them (6 rows) and decreasing the consumed time of sugar beet harvesting.

Increasing the machine performance rate by using two machines for topping and lifting (by using one tractor) is due to increasing the width of them (6 rows) and decreasing the consumed time of sugar beet harvesting.

Effect of forward speed, irrigation system and harvesting machine on broken, bruised, left on soil surface and un-lifted beets.

Figs. 5 and 6 show the effect of forward speed, irrigation system and harvesting machine on broken, bruised and left on soil surface sugar beets. The broken, bruised and left on soil surface sugar beets increased by increasing forward speed from 3.5 to $6.5 \mathrm{~km} / \mathrm{h}$ for all tested harvesting-machines and irrigation-systems. 


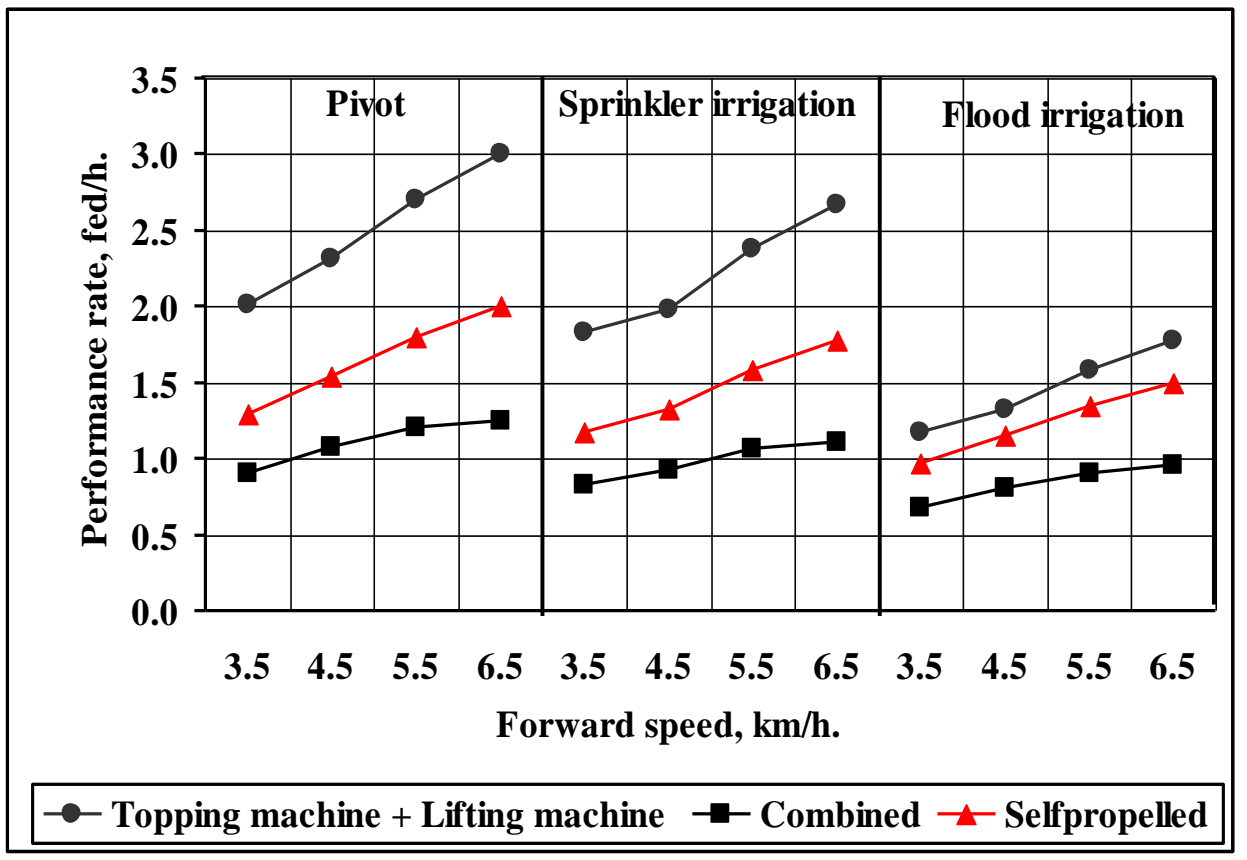

Fig. 4: Effect of forward speed, irrigation system and harvesting machine on machine performance rate.

The broken sugar beets ranges were $0.066-0.120,0.104-0.160$ and $0.081-0.150 \%$, the bruised sugar beets ranges were $0.099-0.180$, $0.156-0,240$ and $0.121-0.225 \%$; and the left on soil surface sugar beets ranges were $2.97-5.40,4.68-7.20$ and $3.63-6.75 \%$ by using two separated machines for topping and lifting, combined and selfpropelled machine respectively for all forward-speeds and irrigationsystems. Decreasing sugar-beet broken, bruised and left on soil surface sugar beets by using two separated machines for topping and lifting is due to increasing the topping and lifting efficiencies.

Effect of forward speed, irrigation system and harvesting machines on sugar-beet total losses.

Fig. 7 shows the effect of forward speed, irrigation system and harvesting machines sugar-beet on total losses.

The sugar-beet total losses increased by increasing forward speed from 3.5 to $6.5 \mathrm{~km} / \mathrm{h}$ for all tested harvesting-machines and irrigation-systems. 

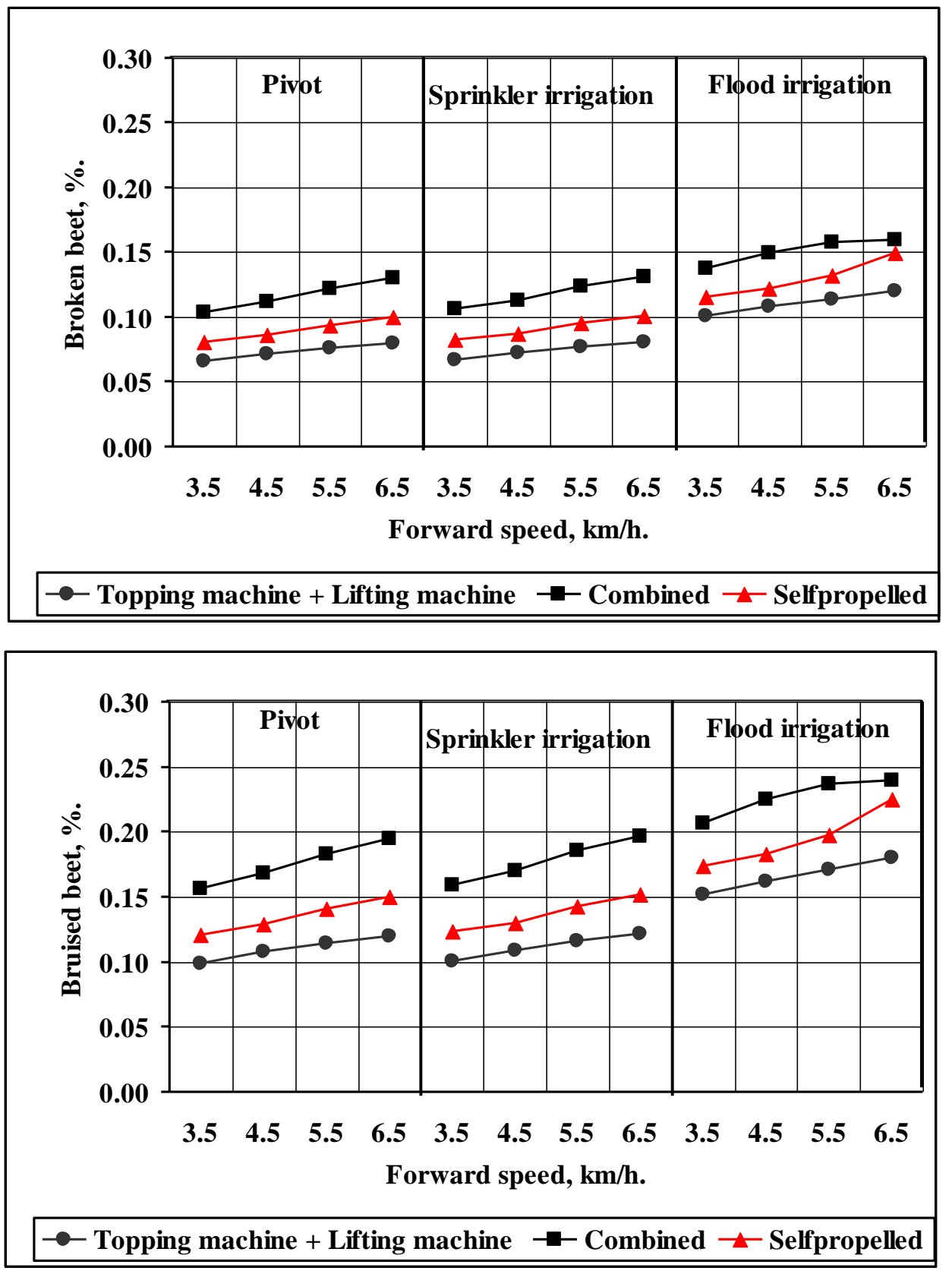

Fig. 5: Effect of forward speed, irrigation system and harvesting machine on broken and bruised beets. 

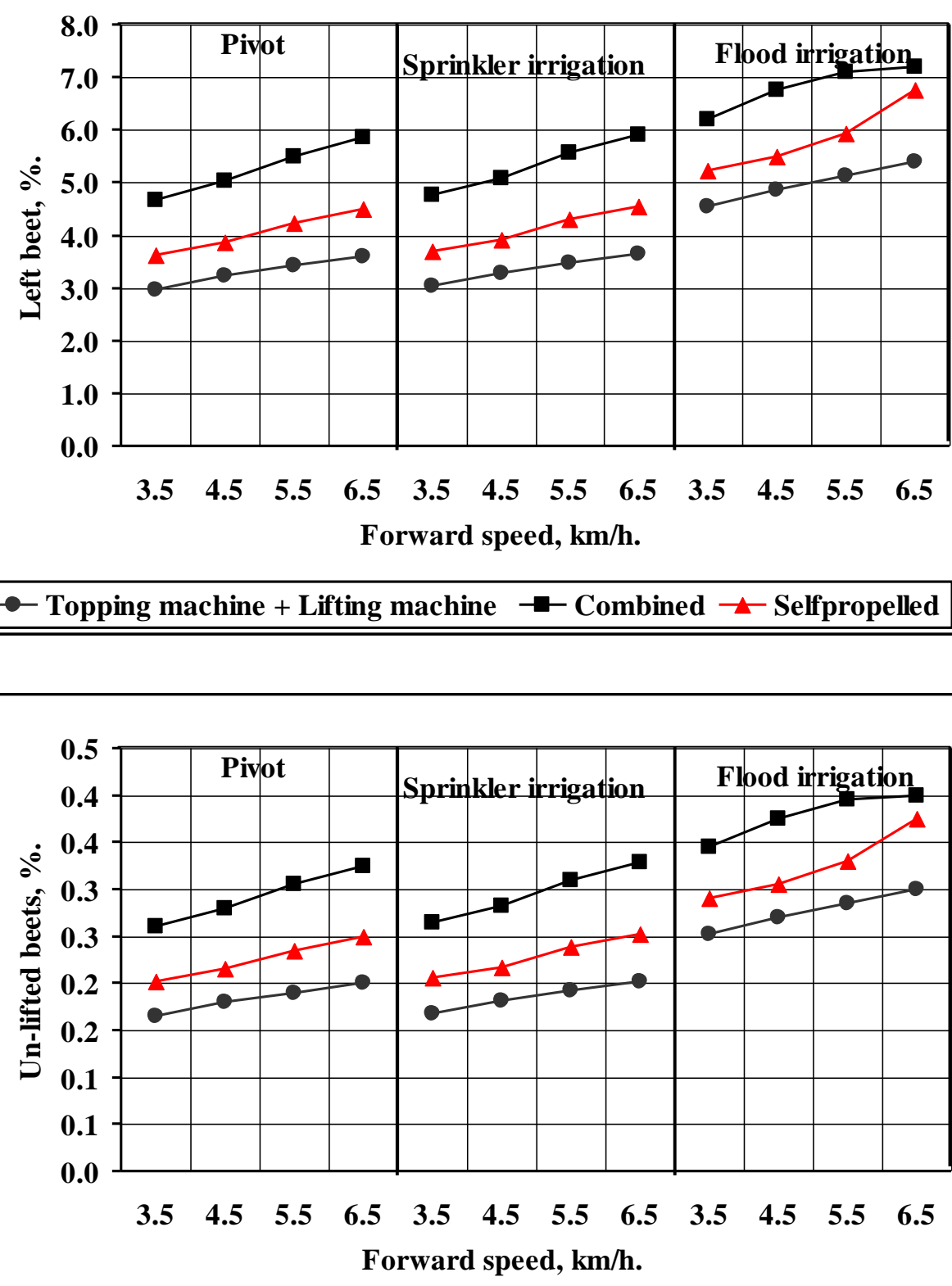

Fig. 6: Effect of forward speed, irrigation system and harvesting machine on left on soil surface and un-lifted beets. 


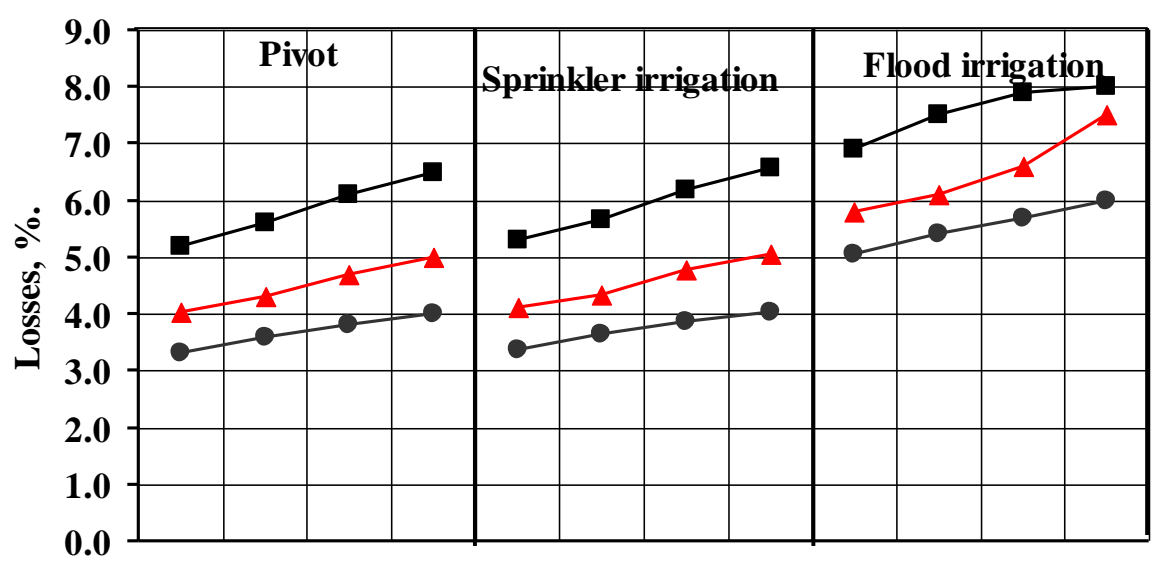

$\begin{array}{llllllllllll}3.5 & 4.5 & 5.5 & 6.5 & 3.5 & 4.5 & 5.5 & 6.5 & 3.5 & 4.5 & 5.5 & 6.5\end{array}$

Forward speed, km/h.

\section{Combined $\rightarrow-$ Selfpropelled}

Fig. 7: Effect of forward speed, irrigation system and harvesting machine on total losses of beets.

By using pivot irrigation-system, the maximum sugar-beet loss of $6.5 \%$ was obtained with forward speed of $6.5 \mathrm{~km} / \mathrm{h}$ and combined harvestingmachine. Meanwhile, the minimum sugar-beet loss of $3.3 \%$ was obtained with forward speed of $3.5 \mathrm{~km} / \mathrm{h}$ by using two separated machines for topping and lifting. Increasing sugar beet losses by increasing forward speed is due to increasing the vibrations of the machine. Meanwhile, decreasing sugar beet losses by using two separated machines for topping and lifting is due to increasing the topping and lifting efficiencies.

Effect of forward speed, irrigation system and harvesting machine on lifting, loading and harvesting efficiencies.

Figs. 8 and 9 show the effect of forward speed, irrigation system and harvesting machine on lifting, loading and harvesting efficiency. The lifting, loading and harvesting efficiencies of sugar beet increased by decreased forward speed from 3.5 to $6.5 \mathrm{~km} / \mathrm{h}$ for all tested harvesting- 


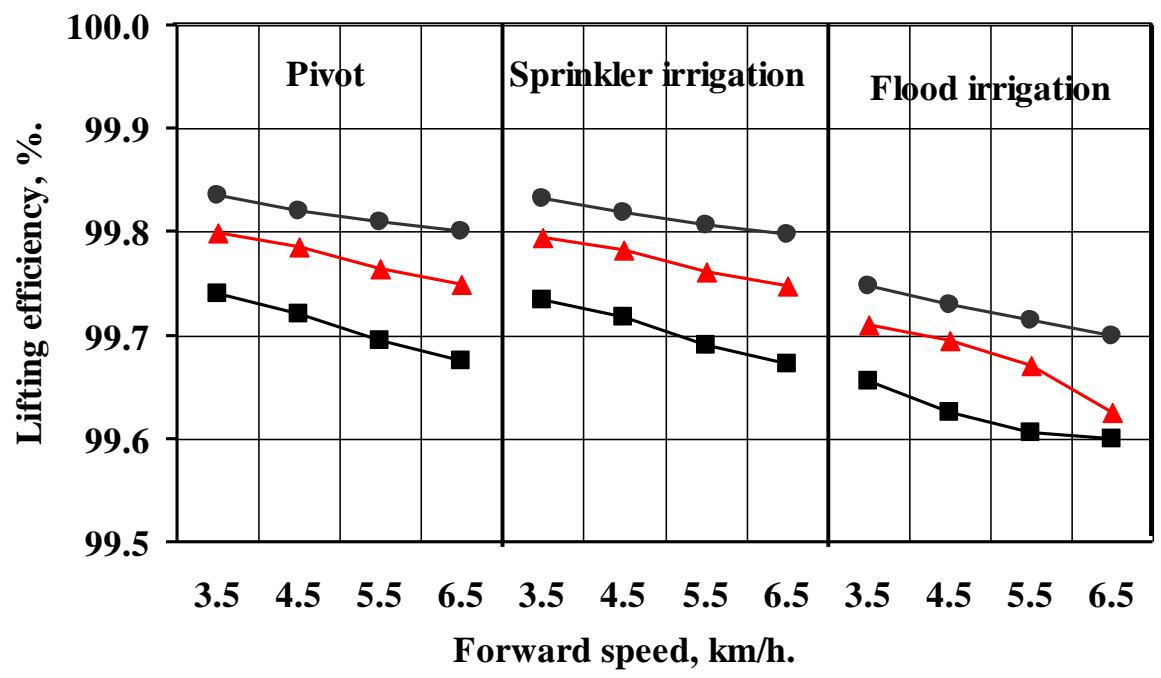

$\rightarrow-$ Topping machine + Lifting machine $\rightarrow-$ Combined $\rightarrow-$ Selfpropelled

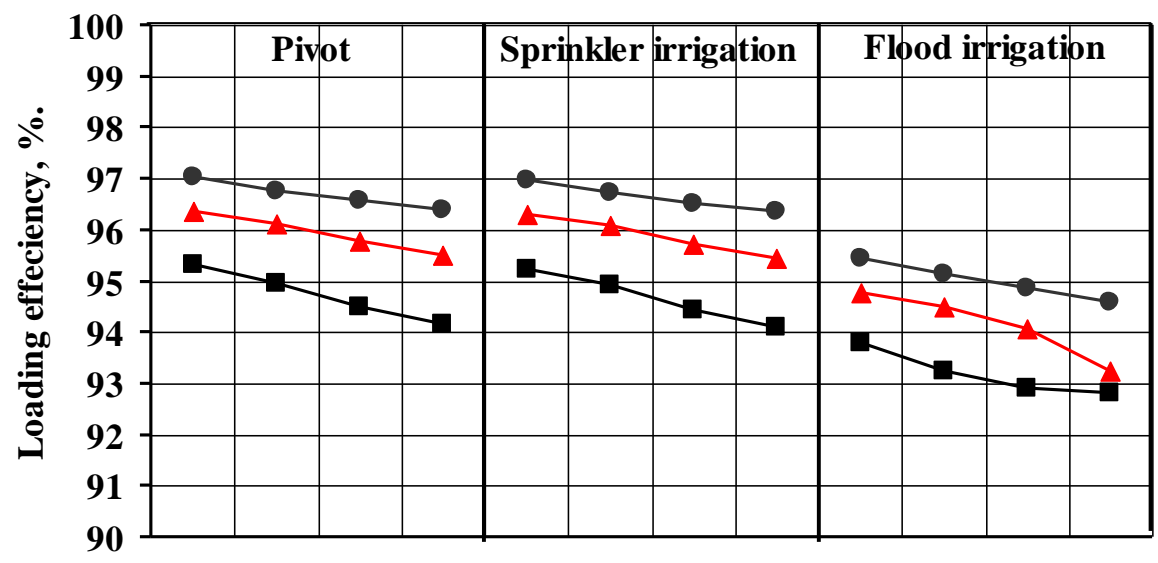

\section{$\begin{array}{llllllllllll}3.5 & 4.5 & 5.5 & 6.5 & 3.5 & 4.5 & 5.5 & 6.5 & 3.5 & 4.5 & 5.5 & 6.5\end{array}$} Forward speed, km/h.

Fig. 8: Effect of forward speed, irrigation system and harvesting machine on lifting and loading efficiencies of beets. 


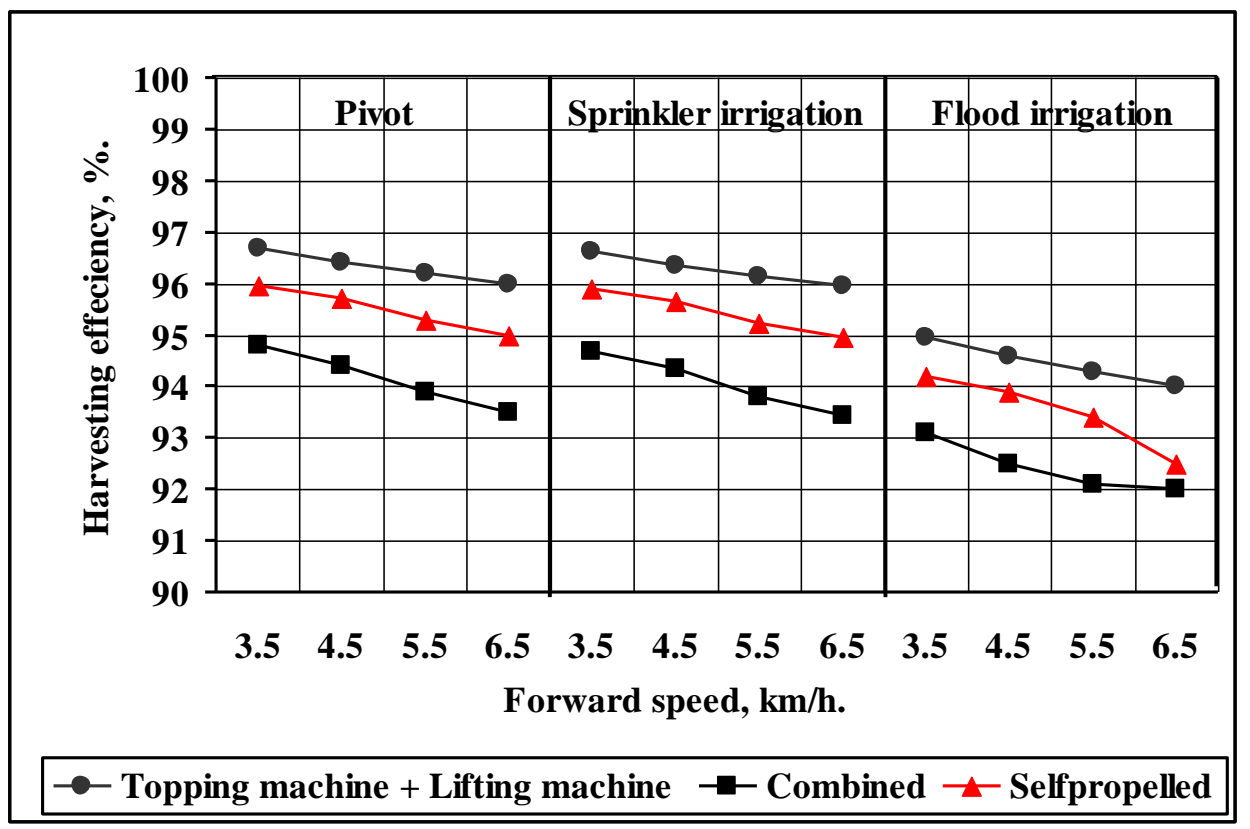

Fig. 9: Effect of forward speed, irrigation system and harvesting machine on harvesting efficiency of beets.

The maximum lifting, loading and harvesting efficiencies sugar-beet of 99.84, 97 and $96.7 \%$ were obtained with forward speed of $3.5 \mathrm{~km} / \mathrm{h}$, pivot system by using two separated machines for topping and lifting. Meanwhile, the minimum sugar-beet lifting, loading and harvesting efficiencies of 99.6, 92.8 and $92 \%$ was obtained with forward speed of $6.5 \mathrm{~km} / \mathrm{h}$, flood irrigation-system and combined harvesting-machine.

Decreasing harvesting efficiency by increasing forward speed is due to increasing the vibrations of the machine and increasing harvesting losses accordingly. Decreasing harvesting efficiency by using pivot system is due to increasing a degree of soil leveling and decreasing the vibrations of the machine accordingly.

Effect of forward speed on fuel consumption and specific energy for different sugar-beet harvesting machines.

Fig. 10 shows the effect of forward speed on fuel consumption and specific energy for different sugar-beet harvesting machines. 

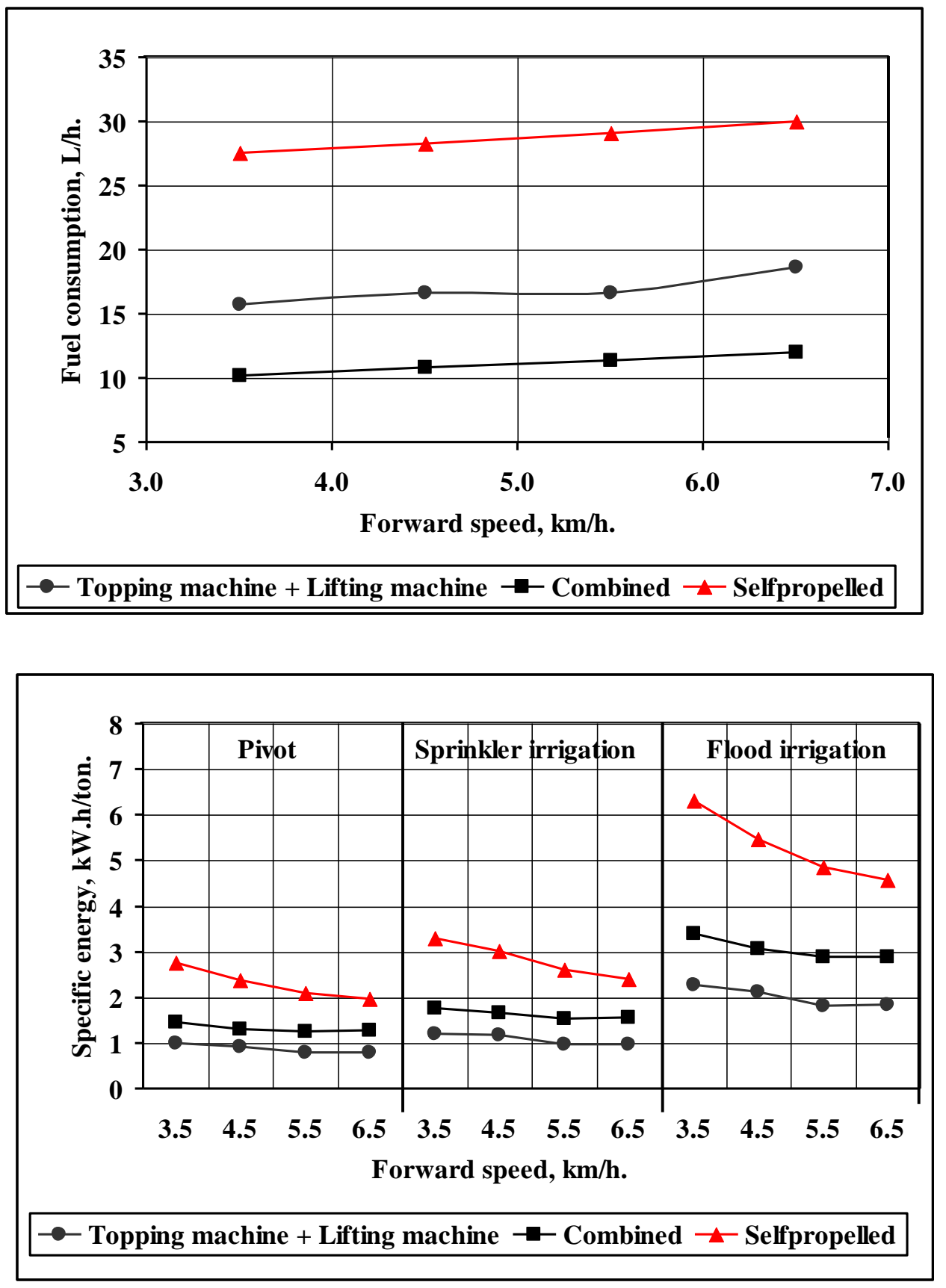

Fig. 10: Effect of forward speed, irrigation system and harvesting machine on fuel consumption and specific energy. 
The fuel consumption increased and specific energy decreased by increasing forward speed from 3.5 to $6.5 \mathrm{~km} / \mathrm{h}$ for all tested harvestingmachines and irrigation systems.

The maximum fuel consumption of $30 \mathrm{~L} / \mathrm{h}$ was obtained with forward speed of $6.5 \mathrm{~km} / \mathrm{h}$ by using self-propelled harvesting machine. Meanwhile, the minimum fuel consumption of $10.22 \mathrm{~L} / \mathrm{h}$ was obtained with forward speed of $3.5 \mathrm{~km} / \mathrm{h}$ by using combined harvester.

The maximum specific energy of $6.31 \mathrm{~kW} . \mathrm{h} / \mathrm{ton}$ was obtained with forward speed of $3.5 \mathrm{~km} / \mathrm{h}$, flood irrigation-system by using self-propelled machine. Meanwhile, specific energy of $0.79 \mathrm{~kW}$.h/ton was obtained with forward speed of $5.5 \mathrm{~km} / \mathrm{h}$, pivot irrigation-system by using two separated machines for topping and lifting.

\section{Effect of forward speed, irrigation system and harvesting machine on sugar beet yield.}

Fig. 11: Effect of forward speed, irrigation system and harvesting machine on sugar-beet yield. By using two separated machines for topping and lifting, the sugar beet yield ranges were $27-27.2,25-25.2$ and $16.5-16.7$ ton/fed for pivot, sprinkler and flood-irrigation systems respectively.

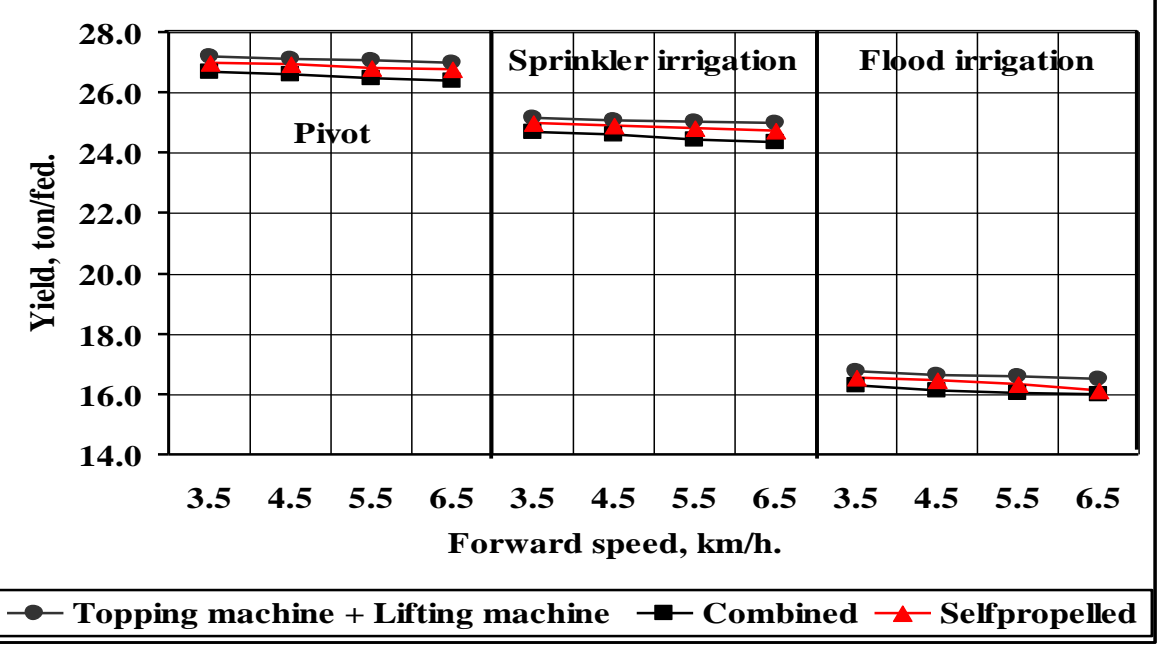

Fig. 11: Effect of forward speed, irrigation system and harvesting machine on sugar beet yield. 


\section{Cost analysis.}

Table 3 shows the operation costs for different harvesting-machines and irrigation-systems at different forward-speeds.

The minimum operation-costs were 17.75 L.E./ton (445.5 L.E./fed) by using 6-rows topping and lifting machines at forward speed of $3.5 \mathrm{~km} / \mathrm{h}$ and pivot irrigation-system. Meanwhile, the maximum operation-costs and were 31.6 L.E./ton (780.9 L.E./fed) by using 4-rows combined harvester at forward speed of $3.5 \mathrm{~km} / \mathrm{h}$ and flood irrigation-system.

The manual-harvesting costs of sugar beet (lifting, topping and collecting at the end of field) are 1500 L.E./fed (30 worker x 50 L.E. for one feddan) and 100 L.E./ton.

The criterion (at different sugar beet harvesting-machines forwardspeeds and irrigation systems) value takes into account the value of resulting crop yield minus harvesting expenses, with all other economical conditions kept constant for comparison. Meanwhile, harvesting expenses include: harvesting cost + beet losses. It is suggested to call this value "Crop Value minus Harvesting Expenses, CVHE".

CVHE $=$ Crop Value - Harvesting Expenses

$=$ Crop Value $-($ harvesting cost + beet loss cost $)$

Crop Value $(\mathrm{LE} / \mathrm{fed})=$ crop prod. $($ ton/fed $) *$ crop sale value $(\mathrm{LE} / \mathrm{ton})$.

The highest criterion value "CVHE" (8761 LE/fed) was obtained with two separated machines for topping and lifting, $3.5 \mathrm{~km} / \mathrm{h}$ and pivot system, and the lowest (4604 LE/fed) was obtained with combined harvester, $6.5 \mathrm{~km} / \mathrm{h}$ and flood irrigation, indicating the economical advantage of harvesting system.

It is observed from tables 3 and 4 that differences in operation expanses and losses are marginal when compared with crop values. However, noticeable differences in crop values result from different harvesting-machines, forward-speeds and irrigation-systems. 
Table 3: Effect of forward speed, irrigation system and harvesting machine on operation cost by L.E./fed.

\begin{tabular}{|c|c|c|c|c|}
\hline \multirow{3}{*}{$\begin{array}{l}\text { Irrigation } \\
\text { system. }\end{array}$} & \multirow{3}{*}{$\begin{array}{c}\text { Forward } \\
\text { Speed, } \\
\text { km/h. }\end{array}$} & \multirow{2}{*}{\multicolumn{3}{|c|}{ Operational cost, L.E./fed. }} \\
\hline & & & & \\
\hline & & $\begin{array}{l}\text { Topping + } \\
\text { Lifting }\end{array}$ & Combined & Self-propelled \\
\hline \multirow{4}{*}{ Pivot } & 3.5 & 445.5 & 780.9 & 661.8 \\
\hline & 4.5 & 387.7 & 658.0 & 554.4 \\
\hline & 5.5 & 331.7 & 587.3 & 474.3 \\
\hline & 6.5 & 298.5 & 568.5 & 426.9 \\
\hline \multirow{4}{*}{ Sprinkler } & 3.5 & 489.6 & 858.1 & 727.3 \\
\hline & 4.5 & 450.8 & 765.1 & 644.6 \\
\hline & 5.5 & 376.9 & 667.4 & 539.0 \\
\hline & 6.5 & 335.4 & 638.8 & 479.6 \\
\hline \multirow{4}{*}{ Flood } & 3.5 & 594.0 & 1041.2 & 882.4 \\
\hline & 4.5 & 516.9 & 877.3 & 739.2 \\
\hline & 5.5 & 442.2 & 783.1 & 632.4 \\
\hline & 6.5 & 396.2 & 740.2 & 569.1 \\
\hline
\end{tabular}

Table 4: Effect of forward speed, irrigation system and harvesting machine on "Crop Value minus Harvesting Expenses, CVHE".

\begin{tabular}{|c|c|c|c|c|}
\hline Irrigation & Forward & \multicolumn{3}{|c|}{ CVHE, L.E./fed. } \\
\cline { 3 - 5 } system. & $\begin{array}{c}\text { Speed, } \\
\text { km/h. }\end{array}$ & $\begin{array}{c}\text { Topping }+ \\
\text { Lifting }\end{array}$ & Combined & Self-propelled \\
\cline { 3 - 5 } & & 8761 & 8421 & 8626 \\
\hline \multirow{4}{*}{ Pivot } & 3.5 & 8712 & 8358 & 8584 \\
\cline { 2 - 5 } & 4.5 & 8679 & 8276 & 8519 \\
\cline { 2 - 5 } & 5.5 & 8646 & 8210 & 8470 \\
\cline { 2 - 5 } & 6.5 & 8049 & 7713 & 7915 \\
\hline \multirow{4}{*}{ Sprinkler } & 3.5 & 8006 & 7660 & 7881 \\
\cline { 2 - 5 } & 4.5 & 7973 & 7578 & 7815 \\
\cline { 2 - 5 } & 5.5 & 7944 & 7519 & 7772 \\
\cline { 2 - 5 } & 6.5 & 5011 & 4729 & 4889 \\
\hline \multirow{4}{*}{ Flood } & 3.5 & 4968 & 4661 & 4858 \\
\cline { 2 - 5 } & 4.5 & 4933 & 4614 & 4798 \\
\cline { 2 - 5 } & 5.5 & 4895 & 4604 & 4682 \\
\cline { 2 - 5 } & 6.5 & & & \\
\hline
\end{tabular}




\section{CONCLUSION}

By using pivot irrigation-system, the maximum machine-performance rate rate of $3 \mathrm{fed} / \mathrm{h}$ and $81 \mathrm{ton} / \mathrm{h}$ was obtained with forward speed of 6.5 $\mathrm{km} / \mathrm{h}$ and 6-rows separated machines for topping and lifting of sugar beet. Meanwhile, the minimum machine-performance rate rate of $0.91 \mathrm{fed} / \mathrm{h}$ $24.30 \mathrm{ton} / \mathrm{h}$ was obtained with forward speed of $3.5 \mathrm{~km} / \mathrm{h}$ and 4-rows combined harvester of sugar beet.

The maximum lifting, loading and harvesting efficiencies of sugar-beet of 99.84, 97 and $96.7 \%$ were obtained with forward speed of $3.5 \mathrm{~km} / \mathrm{h}$, pivot system by using two separated machines for topping and lifting. Meanwhile, the minimum sugar-beet lifting, loading and harvesting efficiencies of 99.6, 92.8 and $92 \%$ was obtained with forward speed of $6.5 \mathrm{~km} / \mathrm{h}$, flood irrigation-system and combined harvesting-machine.

The minimum operation-costs were 17.75 L.E./ton (445.5 L.E./fed) by using 6-rows topping and lifting machines at forward speed of $3.5 \mathrm{~km} / \mathrm{h}$ and pivot irrigation-system. Meanwhile, the maximum operation-costs and were 31.6 L.E./ton (780.9 L.E./fed) by using 4-rows combined harvester at forward speed of $3.5 \mathrm{~km} / \mathrm{h}$ and flood irrigation-system.

\section{REFERENCES}

Agric. Statistics Economic Affair Sector, 2011, Agric. statistics, Economical Issues Sector, Cairo, Egypt: 172-173.

Awady, M. N., 1978, Tractor and farm machinery, Text book, Fac. Ag. Ain-Shams U.: 164-167.

Hunt, D., 1983, Farm power and machinery management, $8^{\text {th }}$ Ed. Iowa state Univ., Press Ames, USA. Ames, Iowa, USA: 364-368.

Hopkinson, I., 1991, Reducing harvester losses. British Sugar Beet Review, 59(3): 26-27.

Raininko, K., 1990, Sweeden sugar beet production. J. of sugar,1(29): 32-62.

Taieb, A.Z., 1990, The demands and constraints of energy utilization in sugar beet crop production, Ph.D. Thesis (Ag. Eng.) Cairo Univ. 
Taieb, A.Z., 1997, Comparative study on manual and mechanical sugar beet planting in the newly reclaimed lands, Misr. J. Ag. Eng., 14 (3): 299309.

Toth, L., 1991, Matrot-M-31 electronic self-propelled sugar beet harvester (for head cutting, picking). Mezogazdasagi-Technika. 32: 10,30. No. 73-1528.

Zaalouk, A.K., 1994, Optimum width and speed for least cost tillage;,Trans. of the ASAE, Paper No. 73-1528.

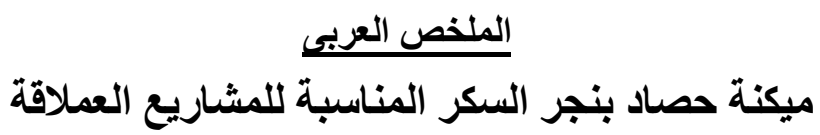

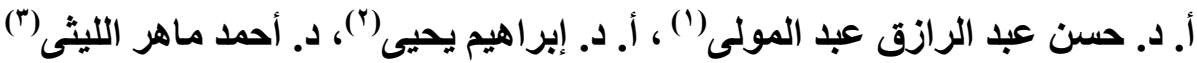

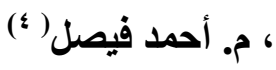

تهدف هذه الدراسة إلى إختبار نظامي الحصاد والرى المناسبين لإنتاج بنجر السكر فى

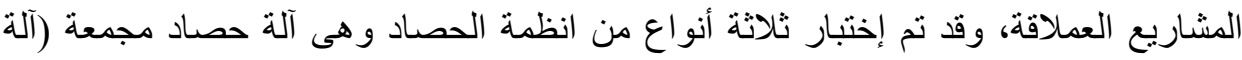
تطويش معلقة أمام الجرار و آلة تقليع مجرورة خلفه)، آلة تطويش + آلة تقليع منفصلتين يعملان بجر ارين مختلفين، آلة ذاتية الحركة وثلاث أنظمة رى و هيى الرى المحورى وبالرش والر السطى.

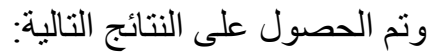

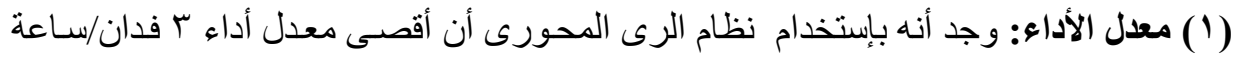

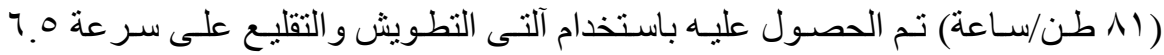

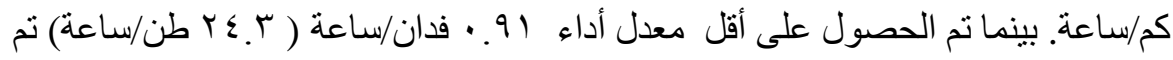
الحصول عليه باستخدام آلة الحصاد المجمعة على سر عة ه. ـ كم/ساعة لنفس نظام الرى.

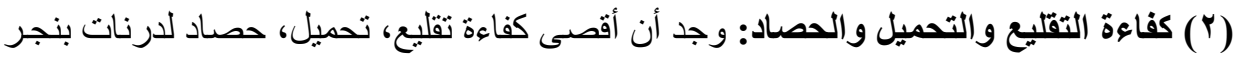

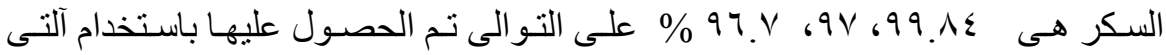

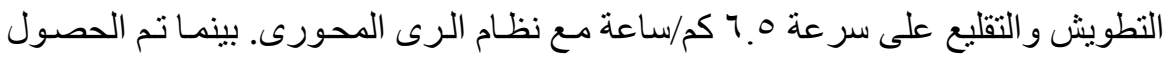

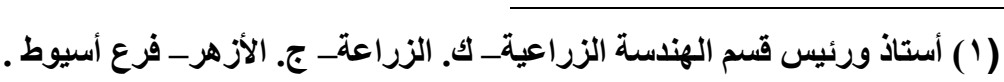

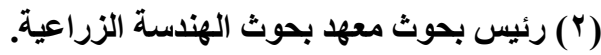

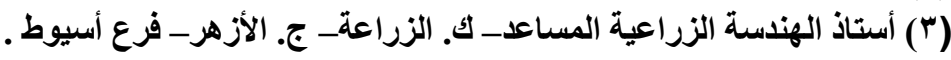

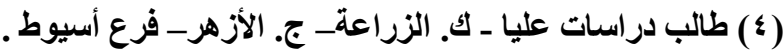




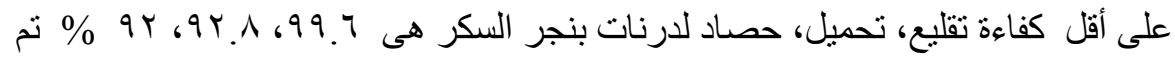

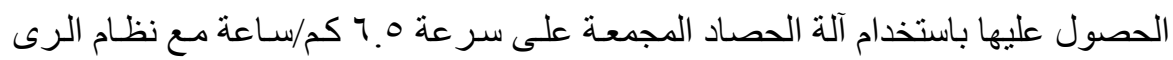
السطحى.

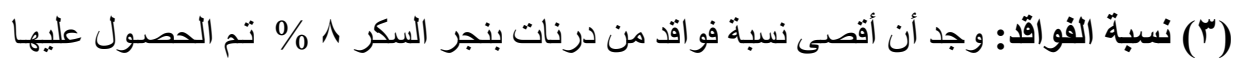
باستخدام آلة الحصاد المجرور ةعلى سر عة هـ ـ كم/ساعة مع نظسام الرى السطحى. بينمـا

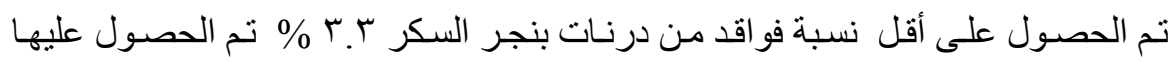
باستخدام آلتى التطويش والتقليع على سر عة هـ كم/ساعة مع نظام الرى المحورى.

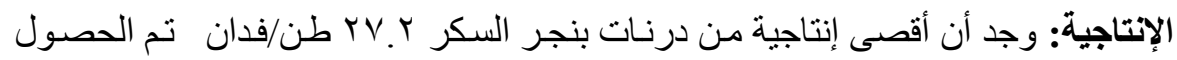

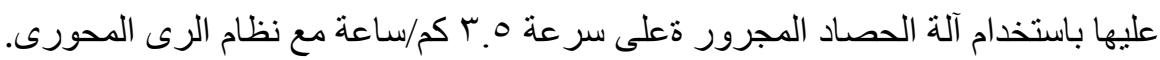

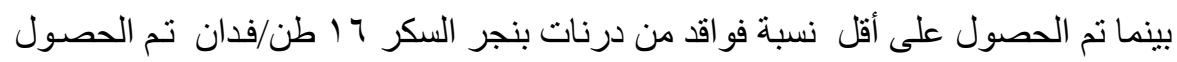
عليها باستخدام آلة الحصاد المجمعة على سر عة ه.7 كم/ساعة مع نظام الرى السطحى.

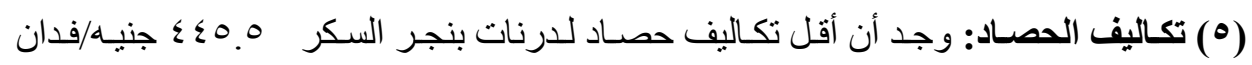

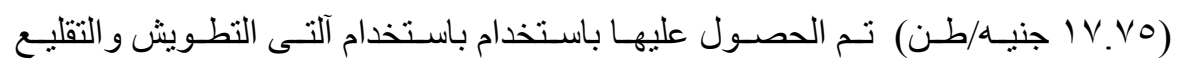

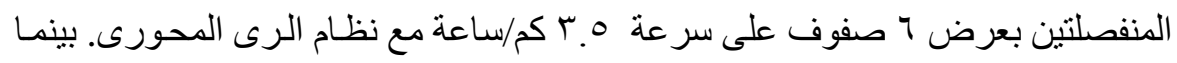

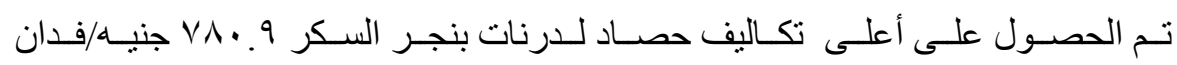

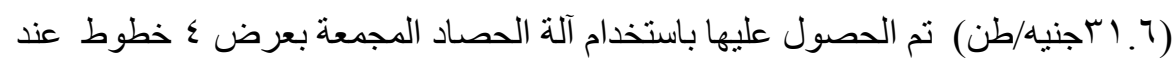
أنسب سر عة تشغيل 0. ب كم/ساعة مع نظام الرى السطحى.

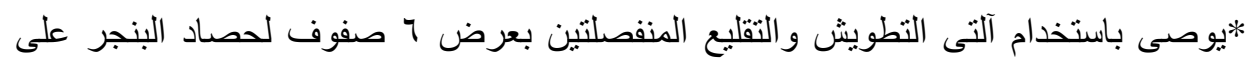
سرعة ه.ب كم/ساعة ونظام الرى المحورى والذى أعطى أن أقل تكاليف حصساد لدرنات بنجر

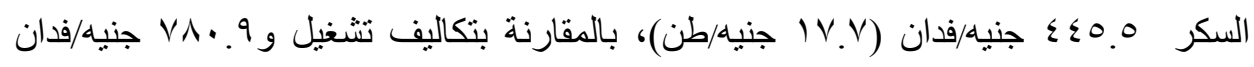
(T. اس جنيه/طن) لآلة الحصاد المجمعة (آلة تطويش معلقة أمام الجرار وآلة تقليع مجرورة

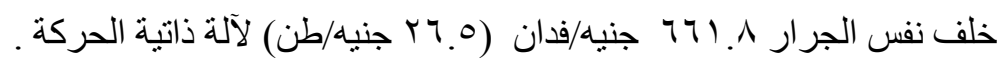

